\title{
CURRENT STATE AND PROJECTION OF THE PROBABLE ORIGINAL VEGETATION OF THE SÃO CARLOS REGION OF SÃO PAULO STATE, BRAZIL
}

\author{
SOARES, J. J., ${ }^{1}$ SILVA, D. W. da ${ }^{2}$ and LIMA, M. I. S. ${ }^{1}$ \\ ${ }^{1}$ Departamento de Botânica, Universidade Federal de São Carlos, UFSCar, CEP 13565-905, São Carlos, SP, Brazil \\ ${ }^{2}$ Departamento de Ciências Biológicas, Universidade do Centro Oeste, CEP 85035-430, Guarapuava, PR, Brazil \\ Corresponding author: João Juares Soares, Departamento de Botânica, UFSCar, Via Washington Luís, km 235, \\ C.P. 676, CEP 13565-905, São Carlos, SP, Brazil, e-mail: juares@ power.ufscar.br \\ Received December 12, 2001 - Accepted August 29, 2002 - Distributed August 31, 2003
}

(With 2 figures)

\begin{abstract}
A map of the native vegetation remaining in São Carlos County was built based on aerial images, satellite images, and field observations, and a projection of the probable original vegetation was made by checking it against soil and relief surveys. The existing vegetation is very fragmented and impoverished, consisting predominantly of cerrados (savanna vegetation of various physiognomies), semideciduous and riparian forest, and regeneration areas. Araucaria angustifolia (Bertol.) Kuntze, found in patches inside the semideciduous forest beginning at a minimum altitude of $850 \mathrm{~m}$, has practically disappeared. By evaluating areas on the map for different forms of vegetation, we obtained the following results for original coverage: $27 \%$ cerrado (sparsely arboreal and short-shrub savanna, and wet meadows); $16 \%$ cerradão (arboreal savanna); 55\% semideciduous and riparian forests; and 2\% forest with A. angustifolia. There are now $2 \%$ cerrados; $2.5 \%$ cerradão; $1 \%$ semideciduous forest and riparian forests; $1.5 \%$ regeneration areas; and $0 \%$ forest with $A$. angustifolia.
\end{abstract}

Key words: vegetation fragmentation, cerrado, semideciduous forest, Araucaria angustifolia, forest remnant, phytogeography.

\section{RESUMO}

\section{O município de São Carlos, São Paulo, Brasil: vegetação original e situação atual}

Um mapa dos remanescentes da vegetação nativa existente no município de São Carlos foi construído por intermédio de imagens aéreas, imagens de satélite e observações de campo. Foi realizada também projeção da provável vegetação original pelo cruzamento dos remanescentes com os levantamentos pedológicos e altimétricos. A vegetação atual encontra-se bastante fragmentada e empobrecida predominando cerrado com diferentes fisionomias, floresta estacional semidecídua, mata ripária e capoeira. A. angustifolia (Bertol.) Kuntze, que aparentemente se encontrava em manchas no interior da floresta semidecídua na cota mínima de $850 \mathrm{~m}$, praticamente desapareceu. Por meio dos cálculos das áreas estimadas para as diferentes formas de vegetação, verificou-se que o município era ocupado por $27 \%$ de cerrados (cerrado sensu stricto, campo sujo e brejos), $16 \%$ de cerradão, $55 \%$ de floresta semidecídua e mata ripária e $2 \%$ de floresta semidecídua com A. angustifólia. Atualmente, há $2 \%$ de cerrados, $2,5 \%$ de cerradão, $1 \%$ de floresta semidecídua e ripária, $1,5 \%$ de capoeiras e $0 \%$ de floresta semidecídua com A. angustifolia.

Palavras-chave: fragmentação da vegetação, cerrado, floresta semidecídua, Araucaria angustifolia, remanescentes florestais, fitogeografia. 


\section{INTRODUCTION}

São Carlos County is located in the central region of São Paulo State, between $21^{\circ} 30^{\prime} \mathrm{S}, 47^{\circ} 30^{\prime} \mathrm{W}$ and $22^{\circ} 30^{\prime} \mathrm{S}, 48^{\circ} 30^{\prime} \mathrm{W}$. Its maximum altitude is about $950 \mathrm{~m}$ with a minimum of $520 \mathrm{~m}$. The topography is flat to slightly hilly, with accentuated scarps and slopes in some regions. The climate of the region is classified between CWA and AW in Köppen's system, representing a transition from hot tropical with dry winter climate to tropical with dry summer and humid winter (Embrapa-CCPSE, 1999). The average annual rainfall is $1468 \mathrm{~mm}$, with rain predominating between November and February. Frost usually occurs once or twice a year, mostly in higher areas.

According to Brasil-Embrapa (1982), the region presents different soil types of varying aluminum content and fertility. They include: structured purple soil, purple latosol, dark red latosol, red-yellow latosol, lithosol, deep quartz sands, redyellow podsol, and hydromorphic soil.

The current vegetation is very heterogeneous, due partly to climatic conditions and the soil but mainly to human interference. Very fragmented, it consists mainly of cerrados (sparsely arboreal savanna, short-shrub savanna, and wet meadows), cerradão (arboreal savanna), semideciduous and riparian forests, and regeneration areas.

\section{The soils, the relief, the hydrology and the original vegetation}

Neves (1983) describes the soils and vegetation of São Carlos County as follows: "The lands currently making up São Carlos County are located on the edge of the São Paulo western plateau, the last buttress of the wide southern arenaceous-basaltic highland. Crowning the plateau at altitudes of up to nine hundred and a thousand meters, the county lies across sinuous scarps cut here and there by watercourses that flow down to a surrounding peripheral depression, more than three hundred meters below. Their craggy ridges, facing southeast, are irregular and undulating, forming curious geological patterns, tables, mortar-and-pestles, and iselbergs, which modern geographers call 'witness hills', and silent sentries standing out sharply from the surrounding eroded areas. Close to the base of the scarps and climbing from their to the top since time immemorial, intricate and dense vegetation has grown, copiously nourished by irregular patches of red soil, resulting from the decomposition of basal rocks from ancient lava flows. Figueira branca and paus d'álho trees predominate on the higher grounds, which the handed-down wisdom of the people identified as signs of good soil. There was also a rich flora of perobas, urindiúvas, sucupiras, guarantãs, cedros, ipês, cabreúvas, alecrins, timbós, canjaranas, canelas, saguarajis, araruvas, and faveiros. Higher up, on ridges swept by the south wind, grew whole woodlands of araucaria..."

The same author continues: "Behind this barrier, the lands of São Carlos were protected from settler invasion until the end of the 1700s. Before that, only the naked feet of indigenous guaianá had walked through them for centuries, in their nomadic wanderings".

Southey (Braga, 1994) attests that "these Indians lived on game and wild fruit, "mainly pine seeds', which they stocked, later submitting them to a process similar to the one used to prepare barley for the making of beer".

Braga (1994) mentions the planting of pine trees by the indigenous population, indicating to the existence of "a very ancient pine plantation" on the right-hand side of the railroad, three to four minutes away from the colony station.

The same author describes the relief and the vegetation in the following way: "The territory of the district is rough. There are open savannas and forests. They generally extended through the mountainous region and have been largely felled by the farmers, who have replaced them with verdant coffee plantations. In these areas the soil is, as a rule, very fertile. There are vast stretches of land whose soils are formed by the oxidation and breaking down of igneous rock - diorite (commonly known as ironstone), which has turned into the famous purple soil, of inexhaustible fertility. The open savanna is usually slightly undulating and abundantly sandy; and, specially in the southwest, by the Campo Alegre station, it is adorned with beautiful meadows, of pleasant aspect". Regarding hydrology he mentions: "The district is bathed by the Rivers Feijão, Lobo, Onça, Pinhal, Quebra-Canella, Mello, Monjolinho, Chibarro, Mineirinho, Corrente e Jacaré, which discharge into the Tietê; and by the Águas Turvas, dos Negros, Quilombo, da Água Vermelha, das Araras and das Cabeceiras brooks, tributaries of the Mogy-Guassú river, that also bathes the district".

The devastation of the original areas of vegetation was a consequence of the large-scale use of soil for agriculture and pasture, beginning with the expansion of coffee planting after 1860. Until 
then, activity had been restricted to subsistence crops and breeding carried out by the inhabitants, useful also in supplying muleteers and travelers as they moved toward Brazil's central region (Truzzi, 2000).

In this period, semideciduous forest yielded to agriculture due to the demand for more fertile soils for coffee plantation expansion. Besides the loss of good part of the forests, even the remaining fragments were used to produce coffee seedlings and, consequently, the underwood was cleared, causing impoverishment and reduction of biodiversity in these areas, in the interior of which numerous coffee plants may still be found (Martins, 1991; Silva \& Soares, 2000) The native pine [Araucaria angustifolia (Bertol.) Kuntze], which is used as the official symbol of the county, and was apparently found in patches in the semideciduous forest, has practically disappeared, due to its use for timber and its felling during land occupation. Today, only a few isolated individuals survive.

The coffee period was followed by those of cotton and citrus fruits, together with rice, corn, beans, and tobacco, resulting in even more fragmentation of rural land and further decreasing native vegetation areas (Silva, 1996).

At the end of the 1930s, the furniture industry of São Carlos expanded greatly supplied by plentiful raw material from sawmills (Truzzi, 2000). Probably, a good part of the wood came from cabreúvas, ipês, and other regional hardwoods.

Cattle-raising expansion occurred on poorer soils, occupied mainly by savanna vegetation. In the 1970s the region became one of the largest milk basins in the state. Thus, a big part of open savanna gave way to pastures. The rise of sugarcane planting began on more fertile soils, replacing coffee and other crops. The presence of the alcohol and sugar industries, with their new techniques and new varieties of species, gave rise to a new agricultural cycle which included the less fertile soils like those of savanna and arboreal savanna.

\section{Current vegetation}

The few fragments of original vegetation are extremely impoverished due to selective cutting of species, mainly by hardwood suppliers, but also by constant accidental fires occurring during sugarcane preparation before cutting or in pasture renewal, or even those criminally caused so as to decrease the environmental value of the native areas.

The aims of the present work are to analyze current vegetation and make a projection of the original one, in order to create a basis for studies of environmental planning and recovery of degraded areas. Similar studies on a larger scale have been done by Borgonovi \& Chiarini (1965), Troppmair (1974), and Fundação SOS Mata Atlântica (2001).

\section{METHODOLOGY}

From photographs taken in 1994 by DEPRN (Natural Resources Protection Department, São Carlos), the surviving pockets of native vegetation in the São Carlos County (excluding cultivated areas) were identified and located. The data from these images were updated with the aid of satellite Landsat images (Embrapa, 2002) and field observations, adding areas in recovery or in the process of reforestation, and omitting areas undergoing vegetation clearance. On the basis of these data the authors elaborated a map showing current native vegetation in São Carlos.

From this map, a projection of the primitive pattern of vegetation was made, based on data from the Soil Survey of the region (Brasil-Embrapa, 1982) as well as on a Topographical Chart and an Altimetry Chart (IBGE, 1971), these last with the aim of locating the probable areas previously occupied by $A$. angustifolia. Thus, according to the kind, or kinds of soil on which the remnants of original vegetation are presently found and taking into account an approximate map of the old areas was drawn of cerrado (savanna), cerradão, semideciduous forest with riparian forest, and areas of concentration of A. angustifolia. The density of araucaria in particular was defined based on information about soil fertility and altitude generally required by the species, since the areas it previously occupied had disappeared, with just a few isolated individuals remaining. In this case, a minimum altitude of $850 \mathrm{~m}$ for its distribution was assumed.

The images were processed with Imagepals GO software. ImagePró 7.4.0 software was used to determine the areas and their percentages.

The data on the vegetation were based on the literature cited in the body of the text and on observations and studies conducted by the authors.

\section{RESULTS AND DISCUSSION}

\section{Distribution of vegetation}

The projection of the original distribution of semideciduous and riparian forest, forest containing A. angustifolia, cerrados, and cerradão is shown in Fig. 1. The estimated total areas of the various vegetational forms, given as percentages of the total 
area of São Carlos were: $27.74 \%$ cerrado, $16.14 \%$ cerradão, $54.36 \%$ semideciduous and riparian forest, and $1.76 \%$ semideciduous forest with $A$. angustifolia (Table 1).

These results show the predominance of riparian and semideciduous forest, the latter developing next to the former and representing, in some cases, a transition between these humid forests and the cerradão and cerrado. The cerrado must have predominated over the cerradão, due to the soil type that it occupies. The semideciduous forest, which supposedly sheltered A. angustifolia stands, occupied the higher areas where remnants of native forest have disappeared.

Nowadays (Fig. 2) there are approximately $2.31 \%$ cerrado, $2.63 \%$ cerradão, $1.09 \%$ semideciduous and riparian forest, $1.58 \%$ forests in early capoeira stage, and $0 \%$ semideciduous forest with $A$. angustifolia. Altogether, of these primitive areas, only $7.61 \%$ of the original native vegetation remains.

Original riparian forest fragments remaining are small and considered permanently preserved areas. Before present-day protective legislation came into effect, the majority of them had already disappeared. The cerrado, previously dominant, was the vegetation that suffered most, probably because it occupied flatter areas easily transformable into pastures. Cerradão was also largely eliminated, but less so than the cerrados, as its forest-like physiognomy made it harder to clear, and the soil it covered was, in general, poorer than that of the semideciduous forest. The latter, which once occupied large areas of the region, is reduced to a few fragments with a high degree of degradation.

Owing to the variety of types of vegetation and their physiognomies, the county, in spite of its considerably degraded native vegetation, presents a rich and varied flora. In the HUFSCar herbarium, there are already more than 980 catalogued native plant species, although it is believed that not even half of the existing regional species have been collected. There are several locations, not yet visited by the researchers of this institution, that may increase this number.

\section{Cerrados and cerradão}

In São Paulo State, savanna occurs in the form of islands or branches, mainly in a central strip from the northwest to the southeast, which includes São Carlos County (Borgonovi \& Chiarini, 1965). These islands comprise the physiognomies of cerradão (arboreal savanna), cerrado, (sparsely arboreal savanna), campo cerrado (short-shrub savanna), and campo sujo (grassland sparsely shrubbed), following Coutinho's classification (1978).

Silva (1994) compared the vegetation and soil characteristics in different savanna physiognomies on Canchim Farm, São Carlos, and concluded that the dominant factor in the distribution of physiognomies was the presence of more or less sandy soils. The sandier soils, with smaller amounts of clay, are poorer in nutrients and more easily washed away by strong summer rainfalls. In richer soils, vegetation is denser and higher but as the soil becomes sandier and poorer, the arboreal and shrub vegetation becomes lower and sparser. This author found, besides the variation in physiognomy, variation in morphological characteristics such as hair density, presence of protective scales, and hardness and size of leaves.

For the São Carlos it was concluded that cerrado predominated over other physiognomic forms. We believe that campo sujo and campo cerrado occurred only in some very restricted areas, mainly in old sandy alluvial deposits.

TABLE 1

Original and current coverage in percentages of native vegetation in São Carlos, SP, Brazil.

\begin{tabular}{|l|c|c|c|}
\hline \multirow{2}{*}{ Physiognomy } & \multicolumn{2}{|c|}{ Coverage (\%) } & \multicolumn{1}{c|}{$\begin{array}{c}\text { Percentage of } \\
\text { original coverage }\end{array}$} \\
\cline { 2 - 3 } & Original & Remnants & 16.29 \\
\hline Cerradão (arboreal savanna) & 16.14 & 2.63 & 8.32 \\
\hline Cerrado (Scrub and field savanna) & 27.74 & 2.31 & 2.00 \\
\hline Semideciduous and riparian forest & 54.36 & 1.09 & 0 \\
\hline Semideciduous forest with Araucaria & 1.76 & 0 & - \\
\hline Degraded forest & 0 & 1.58 & - \\
\hline Total & 100 & 7.61 & \\
\hline
\end{tabular}




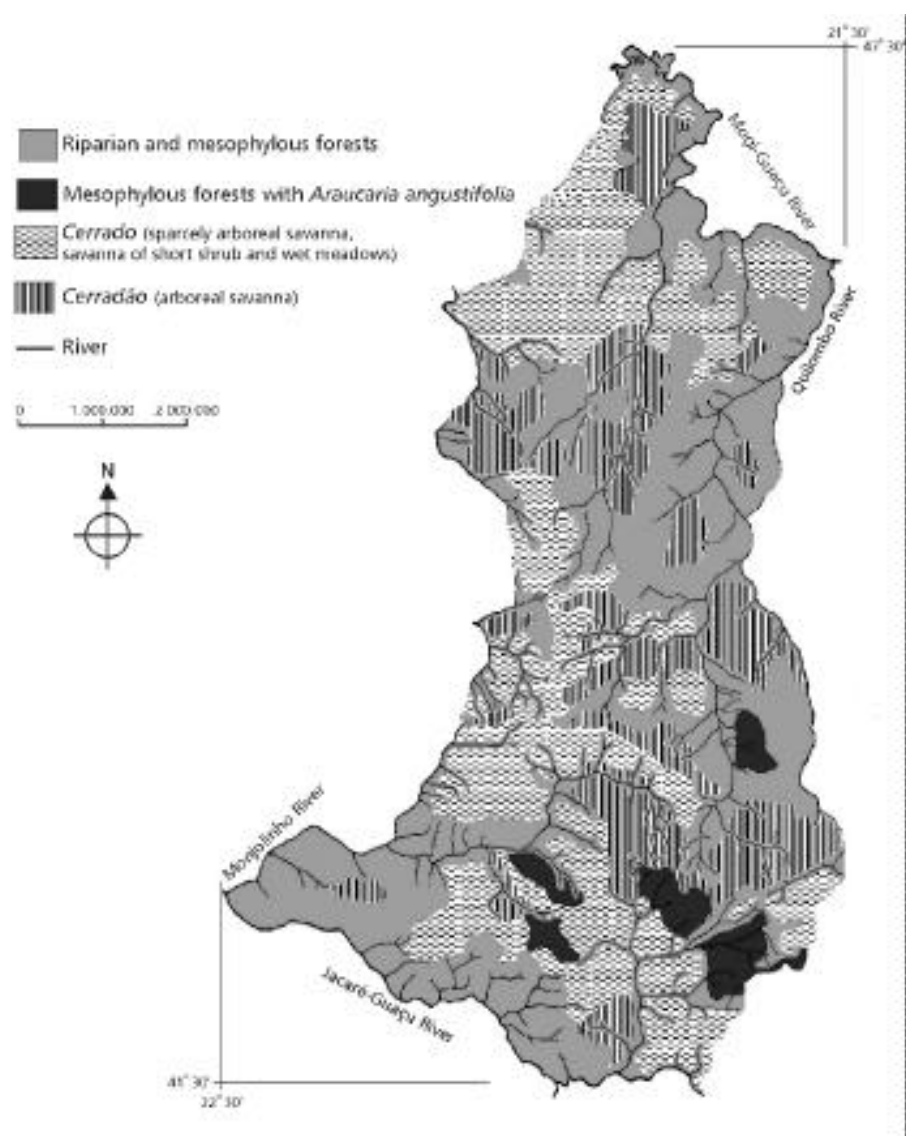

Fig. 1 - Projected original vegetation of São Carlos County São Paulo, Brazil.

Similarly, the wet meadow region formed where a water sheet bursts out between riparian forest and adjacent savanna formations (cerrado, campo cerrado, and cerradão), which is common in many areas of the country, is restricted in São Carlos County, when it occurs at all, to a strip of a few meters.

Much of the remaining savanna formations have a considerably more open physiognomy than the original, due to fires and pasture formation. The cerrado and campo cerrado characteristic species regenerate more easily than the cerradão when the area is abandoned. Although regeneration is facilitated by the species' ability to sprout from the subsoil, it only occurs in places where the agricultural practices do not involve digging deep into the soil. Thus, the surviving savanna does not always reflect past physiognomy.

In the cerrado the underwood and the interlacing branches of stunted trees, growing just above the ground, form a typical landscape: low, dense, and tortuous, hindering attempts to walk through it. From this characteristic derived the term cerrado for this vegetational physiognomy. Researchers like Coutinho (1978) extended the use of this term to more open savanna physiognomies and taller arboreal savanna, owing to the similarity of their flora. The latter, although very similar, within its different physiognomies, varies in density of each species, with sometimes more arboreal species developing and sometimes more shrubs or herbs.

Cerradão is the forest physiognomy of this vegetation. The trees can reach $20 \mathrm{~m}$ in height, with stem diameters exceeding $50 \mathrm{~cm}$. Lianas are found everywhere while the herbaceous stratum is very poor. It occurs generally on soil of average fertility.

This savanna has a rich flora in terms of species. Many of them are valued as decorations and used in arborization of streets and public squares (Almeida et al., 1998), or cultivated for their medicinal properties (Siqueira, 1981) or fruits (Almeida, 1998). 


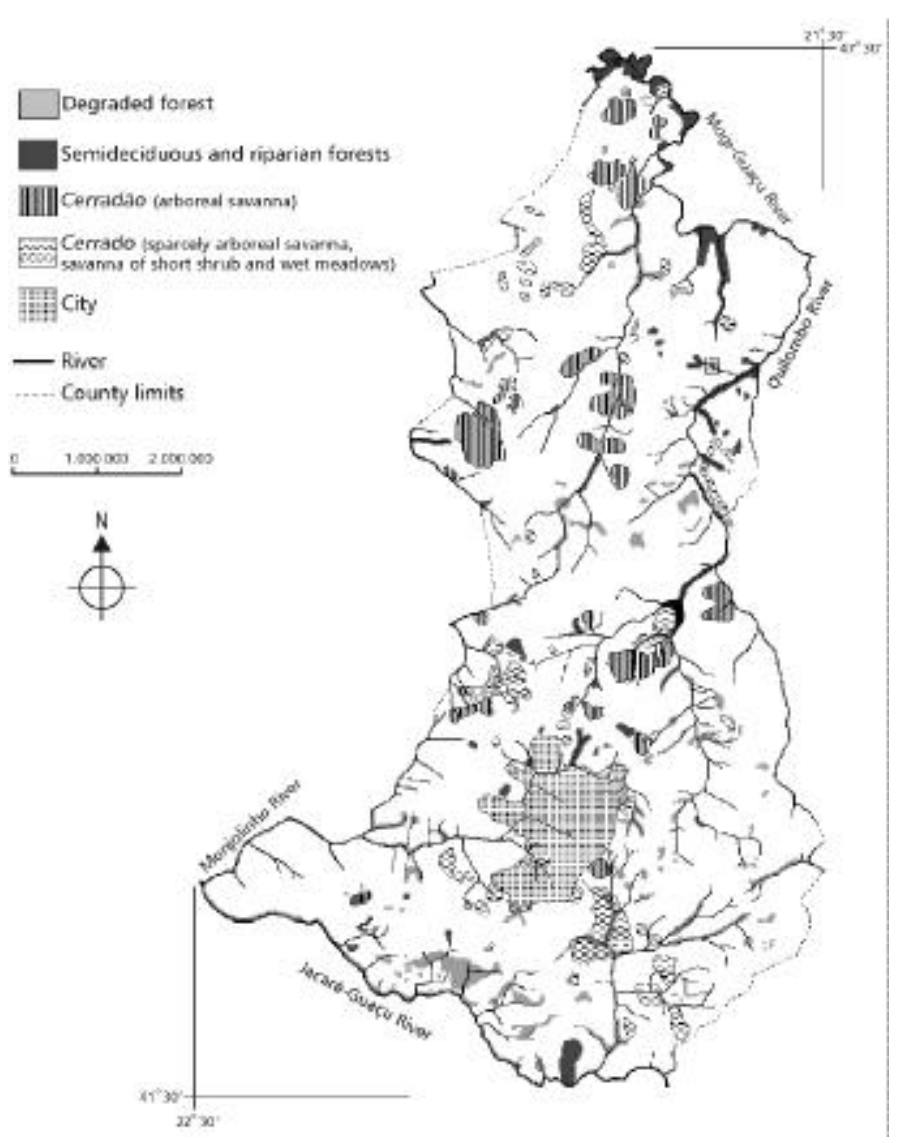

Fig. 2 - Present vegetation of São Carlos Couty, São Paulo, Brazil.

In the regional cerradão we found predominating, in the arboreal stratum, species like Anadenanthera falcata Speg., Bowdichia virgilioides H. B. \& K., Copaifera langsdorffii Desf., Dimorphandra mollis Benth.., Hymenaea courbaril L., H. stigonocarpa Hayne, Pterodon pubescens Benth., Qualea grandiflora Mart., Q. parviflora Mart.; Virola surinamensis Warb, Vochysia tucanorum Mart., Machaerium acutifolium Mart ex Benth., M. villosum Vog., Sweetia dasycarpa Benth., Miconia rubiginosa Benth, and Kielmeyera coriacea Mart. A more detailed description of the specific composition and structure of this vegetation in the county can be found in Silva (1996).

Species like Annona cacans Warm., A. coriacea Mart., A. crassiflora Mart., Syagrus flexuosa (Mart.), Ocotea pulchella Mart, Ouratea spectabilis Engl., Stryphnodendron barbadetiman (Vell) Mart., S. polyphyllum Mart., Pouteria torta Radlk, Xilopia aromatica (Lam.) Mart., Caryocar brasiliense Cambess., Myrcia lingua (O. Berg.) Mattos, and
Roupala montana Aubl. are some of the short trees and bushes commonly found in the savanna of São Carlos. These species also occur in the cerradão.

In more open formations of campo cerrado we found several species of Campomanesia spp., Solanum lycocarpum A. St. Hil., Casearia sylvestris Sw., Setaria poiretiana Kunt, Bromelia antiacantha Bertol, Andira humilis Mart ex Benth., Cochlospermum regium Pilger, Didymopanax vinosum March, Aspidosperma tomentosum Mart, Hancornia speciosa Gomez, Mandevilla velutina K. Schum, Baccharis dracunculifolia D.C., B. subdentata D.C., B. trimera D.C., Calea cimosa Less, C. hispida (D.C.) Baker, Memora axillaris K. Schum., Gochnatia polymorpha Herb. Berol ex D.C., Mikania cordifolia Willd, $M$. micrantha H. B. \& K., Vernonia apiculata Mart. ex D.C., $V$. brevifolia Less., V. ferruginea Less., Anemopaegna arvense (Vell.) Stelfeld ex de Souza, Arrabidaea brachyopoda Burr., Jacaranda caroba D.C., Pyrostegia ignea Presl., Tabebuia aurea Benth 
and Hook f. ex S. Moore, Tabebuia caraiba Bureau Mart., Zeyhera montana Mart., Ananas ananassoides (Barker) L.B. Smith, Bauhinia holophylla (Bong) Steud., Cassia spp., Kielmeyera variabilis Mart., Davilla rugosa Poir., Diospyros hispida A.D.C. Erytroxylum spp., and lianes of the genera Banisteria, Banisteriopsis, and Byrsonima. Trees and short trees of higher physiognomic formations are also, though sparsely, among these species.

In the wet meadows we observed terrestrial orchid species of the genus Habenaria; Xyris jupicai Michx., X. metallica Klotzsch ex. Seub., X. hymenachne Mart., $X$. savanensis Miq., $X$. teres Alb. Nilsson., Andropogon leuchostachyus H.B.K., several species of Miconia and Leandra, Heleocharis interstincta (Vahl) Roem. \& Schult, H. mutata (L.) Roem. \& Shult, Rhynchospora exaltata Kunth., R. globosa (Kunt) Roem. \& Schult, Scirpus cubensis Kunth., Scleria hirtella Bach., Eriocaulon aequinoctiale Ruhl., E. modestum Kunt., E. pygmaeum Dalz., Paepalanthus blepharocnemis Mart ex Koem, $P$. speciosus (Bong.) Koern, Syngonanthus caulescens (Poir) Ruhland, S. fischerianus (Bong.) Ruhland, S. xeranthemoides (Bong) Ruhland, and others such as Hydrocotile bonariensis Lam., Lycopodium spp., Nymphoides indica (L.) O. Ktze. (which develop from the edge of the water bodies), Ludwigia elegans (Cambess) Hara, L. leptocarpa (Nutt.) Hara, $L$. longifolia (D.C.) Hara, L. multinervia (Hook \& Am.) T.P. Ramamoorthy, L. suffruticosa Walt., Pontederia cordata Larranaga, and $P$. lanceolata Nutt.

\section{Riparian forest}

The forests that extend along the riversides have received, through the years, denominations such as alluvial, riparian, gallery, and ciliate forest, among others. According to Ivanauskas et al. (1997) these formations have received the most varied designations owing to the variety of local characteristics, such as relief, soil, declivity, physiognomy, position in the landscape, and so on. Velozo \& Goes Filho (1982) named them alluvial forests and, when alluvial soil under laid the meadows, they were called fluvial alluvial forest (Campos, 1912) or marshy forest (Lindman \& Ferri, 1974; Fernandes \& Bezerra, 1990). Bertoni \& Martins (1987) called them meadows and Troppmair \& Machado (1974), used the term condensation forest, when they occupied the valley bottom, where thick fog occurred at certain periods of the year.

As these formations border the water like eyelashes (Campos, 1912), they were also called rampart forest (Lindman \& Ferri, 1974) and ciliary forest (Sampaio, 1938; Hueck, 1972; Bezerra,
1975). In the State of São Paulo, the term ciliary forest (mata ciliar) was sanctioned by Leitão Filho (1982), who defined it as broad-leaved wet forest with periodic flooding.

The ciliary forest designation has been used as a synonym for the term gallery forest (Joly, 1970; among others). However, the Ecology Glossary (Aciesp, 1987) differentiates between these terms based on forest width and the vegetational physiognomy of adjacent areas. According to this work, gallery forest is forest formations along watercourses, in regions where the interfluvial original vegetation is not forest. For regions where interfluvial original vegetation is also forest, the glossary suggests the term ciliary forest or waterside forest. The term ciliary forest, defined by Aciesp (1987), has been substituted by riparian forest (Bertoni \& Martins, 1987; Catharino, 1989; Mantovani, 1989; Rodrigues, 1992), reserving the term ciliary forest, as used in the current legislation, for more generic commonly used designations (Rodrigues, 2000).

Swamp forest, also described as almost permanently flooded broadleaf wet forest (Leitão Filho, 1982), although frequently appearing associated with riparian and gallery forest, is distinct from the others, because of almost permanent presence of water in the soil. This saturated soil contributes to the selectivity of species occurring in this formation, and results from their specialized physiology adapted to hydric saturation (Ivanauskas et al., 1997).

According to Leitão-Filho (1982), swamp forest exhibits a relatively small number of very specific species, generally not deciduous, whose uppermost stratum reaches an average of $10-12 \mathrm{~m}$ in height.

Swamp forest is restricted to meadows or flood plains, on low, more or less flat land, found close to sources or in well-defined locations on riverbanks, by lakes, or in natural depressions. In these places there are hydromorphic soils (organic and gley; quartzose and hydromorphic sands; and plinthitic soil among others) forming a relief of low mounds and small superficial channels and presenting an irregular surface where the water flows in a definite direction.

The factors that lead to the occurrence of woods (forest physiognomy) or wet meadow (predominantly herbaceous physiognomy) on typically wet soils are still little known. However, it is believed that some of them relate to drainage, and to the presence of physical impediments in the soil and/or alteration of the original topography. In areas where water remained in the soil for long periods, to the point of almost stagnating, herbaceous vegetable formations would develop; and where the water movement was well-defined in superficial channels, forest formations would develop. 
Because of its predominance on hydromorphic soils, swamp forest has a naturally restricted distribution in São Paulo State. In addition to this fragmentation, swamp-forest occupied areas have been greatly reduced in the recent past, due to programs stimulating agricultural use of the meadows and to construction of hydroelectric plants, the latter inundating a large part of these remnants. Riparian forest, besides protecting the hydrological characteristics of water bodies and the associated fauna, provides ecological corridors for biota. Such corridors can be found in São Carlos County, where the riparian forest of one hydrographic basin is continuous with the riparian forest of another, uniting two large hydrographic basins of São Paulo State drained respectively by the Mogi-Guaçu and Tietê rivers. The link is made through tributaries such as the Jacaré and Quilombo rivers (Fig. 2).

Studies of the flora and plant associations in riparian forest in the basins of the Mogi-Guaçu, Tietê, and their tributaries in São Carlos County show that the following species are common in the area, if we ignore the ecological variations from place to place: Cyclolobium vecchii A. Sampaio, Alchornea triplinervia Muell. Arg., Guarea trichilioides L., Genipa americana L., Duguetia lanceolata St. Hill., Inga vera H. B. \& K., Syagrus romanzoffiana (Cham.) Glassm., Eugenia spp., Picramnia warmingiana Engl., Calophyllum brasiliense Camb., Hymenaea courbaril L., Copaifera langsdorffii Desf., Ixora gardneriana Benth., Lonchocarpus guilleminianus (Tul.) Malme, Aspidosperma peroba Saldanha da Gama, Luehea divaricata Mart, Protium heptaphyllum March, Cecropia pachystachya Trec., Talauma ovata A. St. Hill, Drymis brasiliensis Miers., Calophylum brasiliense Camb., Podocarpus sellowii Klotz. ex Endl., Inga affinis D.C., Rapanea guyanensis Aubl., Cyathea delgadii Sternb., Euterpe edulis Mart, Metrodorea nigra A. St. Hil., Croton floribundus Lund. ex Didr., Xylopia brasiliensis Spreng, and Rollinia silvatica Mart (Bertoni \& Martins, 1987; Rodrigues, 1992; and collection of HUFSCar herbarium).

\section{Semideciduous forest}

Semideciduous forest is known by several names according to the region and the authors. It is distributed on the inland plateaus and in peripheral depressions of the Serra do Mar and Serra Geral towards the interior of the continent (FIBGE, 1993). For some authors, such forest should be categorized as Atlantic forest (SOS Mata Atlântica), although there are floristic differences between them that depend on location (Giulietti, 1992). The forest can be increased by including swamp forest in the northeast and on the upper Uruguay River, on the border between Rio Grande do Sul and Santa Catarina States.

Torres et al. (1997) established relations among climate, soil, and arboreal flora in the São Paulo State forests, based on the possible influences of abiotic factors on the distribution of species and arboreal families. Thirteen surveys in São Paulo State were selected, representing different conditions (location at the ends of coordinates and altitudes, succession stadiums, surveying methods). By constructing phenograms the authors verified that the species studied formed two floristic blocks: hygrophilous (annual average rainfall higher than $2000 \mathrm{~mm}$ and no dry season) and semideciduous forest (total annual average rainfall of about 1400 $\mathrm{mm}$, and variable dry season). The semideciduous forest block was divided in two groups: high altitude (average altitude higher than $750 \mathrm{~m}$, average frost frequency higher than three days/year) and low altitude (below $700 \mathrm{~m}$ ). Each of these groups was subdivided according to soil properties (texture, eutrophy, acid or alkaline dystrophy, iron content).

São Carlos County falls in the semideciduous forest block containing both floristic divisions (below $700 \mathrm{~m}$ and above $750 \mathrm{~m}$ ).

Of São Paulo State, several surveys of the flora and structure of vegetation have been made, such as those of Pagano \& Leitão Filho (1987), and Martins (1991). Of São Carlos there are the studies of Hora \& Soares (2002) and Silva \& Soares (2000) in Fazenda Canchim reserve, one of the best-preserved remnants of this forest in the county.

Remnants of semideciduous forest are, in general, very impoverished due to human interference and their reduced extent, which leads to diversity decrease. Observations in Fazenda Canchim showed that the dense soils of these forests prevent trees from rooting deeply. Roots are therefore predominantly superficial and cannot always withstand strong wind pressures on the treetops, especially those projecting above the canopy. Hence, trees fall, forming clearings. In addition, forest fragmentation makes treetops more wind vulnerable, mainly at the forest edges, and the smaller the fragment, the larger the effect of the winds is.

According to Silva \& Soares (2000) the semideciduous forest shows, in general, an emerging stratum, formed by species that rise above the forest canopy; an arboreal stratum, forming a continuous canopy of about 20-30 meters; and one of smaller trees, less than 10 meters high, besides the shrub and herbaceous strata.

These authors cites as the most common species in the highest stratum Cariniana estrellensis Kunthze, 
Piptadenia gonoacantha Macbride, Chorisia speciosa St. Hil., Enterolobium contortisiliquum Morong. and, among species that predominate in the forest, Metrodorea nigra A. St. Hil., Pachystroma longifolium I. M. Johnston, Aspidosperma polyneuron Muell. Arg., Aspidosperma ramiflorum Muell. Arg., Savia dictyocarpa Muel. Arg., Ocotea odorifera (Vell) J. G. Rohwer, Machaerium stipitatum Vog., Holocalyx glaziovii Taub. ex. Glaziou., Cabralea cangerana Saldanha da Gama, Inga marginata H. B. \& K., Actinostemon communis Pax., Actinostemon concolor Pax., Centrolobium tomentosum Guill. ex Benth. Cavassan et al. (1984) and Martins (1991) also mention, as common species in this forest, Croton salutaris Casar, Guarea trichilioides L., Acacia polyphylla Clos., Nectandra megapotamica (Spreng) Mez., Piptadenia rigida Benth., Gallezia gorazema Moq., and Balfourodendron riedelianum Engl.

\section{Semideciduous forest with Araucaria angustifolia}

The presence of Araucaria angustifolia (Bertol.)

O. Kuntze in the forest is striking. This species is shaped like a chandelier and the trees occupy within the forest structure an emerging position. When the population is sufficiently dense, the tops touch forming a continuous canopy, a configuration more common on higher plateaus in southern Brazil.

Araucaria species are typical in South American temperate and cold regions (Duarte, 1993). Their distribution in Brazil in earlier geological periods was more widespread, with only remnants remaining (Backes, 1983).

Two hypotheses are offered to explain the presence of Araucaria in São Carlos:

Paleoclimatic: occurrence a colder and drier paleoclimate in the tertiary, with Araucaria remaining in places where ecological conditions were favorable (Troppmair, 1974). Ledru et al. (1996, 1998) suggested dating the transition from a dry to a moist climate in $17,000{ }^{14} \mathrm{C}$. yr. BP and also that the presence of Araucaria, Podocarpus, and Drymys pollen can indicate high-moisture conditions in some places. In this case, the existence of $A$. angustifolia has a singular importance in the region of São Carlos, evidencing an ancient ecological condition.

Anthropic: indigenous populations during their migrations might have brought seeds, either planted or left behind while camping, that grew in places where favorable ecological conditions were found.

The forest with Araucaria in Southern Brazil shows a group of plant species differing little from the Atlantic formations (Jarenkow \& Baptista, 1987).
Thus, we believe that in the São Carlos region, Arancaria angustifolia occurred together with the semideciduous forest species, forming associations of larger or smaller density.

\section{CONCLUSIONS}

Floristic data, obtained either by collecting plants in the remnants of native vegetation, or from the literature and herbarium collections, combined with information from aerial photographs, satellite images, topographic and soil surveys, and climatic records, are very useful tools in studying original vegetation formations.

These studies can contribute to the selection of species to be used in reforestation areas, thus avoiding the spread of exotic and often extremely aggressive species in the environment.

The geographic, geological, and climatic characteristics of São Carlos favored the development of several kinds of vegetation and, consequently, a flora of great diversity of species.

For preserving our natural heritage, it is important that county areas selected for restoration, be located especially where the native pine, Araucaria angustifolia, a country symbol, originally occurred. In this way, this and other previously abundant species, which have disappeared from the area or are in danger of extinction, can be rescued from that fate.

\section{REFERENCES}

ACIESP, 1987, Glossário de ecologia. Aciesp, São Paulo, 57p.

ALMEIDA, S. P. de, 1998, Cerrado - aproveitamento alimentar. Embrapa, Planaltina, DF.

ALMEIDA, S. P. de, PROENÇA, C. E. B., SANO, M. S. \& RIBEIRO, J. F., 1998, Cerrado - espécies vegetais úteis. Embrapa, Planaltina, DF.

BACKES, A., 1983, Dinâmica do pinheiro brasileiro. Iheringia, Sér. Bot., 30: 49-84.

BERTONI, J. E. de A. \& MARTINS, F. R., 1987, Composição florística de uma floresta ripária na Reserva Estadual de Porto Ferreira, SP. Acta Bot. Brasilica., 1: 17-26.

BEZERRA DOS SANTOS, L., 1975, Floresta galeria. In: Tipos e aspectos do Brasil. IBGE, Rio de Janeiro, pp. 482-484.

BORGONOVI, M. \& CHIARINI, J. C., 1965, Cobertura vegetal do Estado de São Paulo I. Levantamento por fotointerpretação das áreas cobertas com cerrado, cerradão e campo em 1962. Bragantia, 24: 159-172.

BRAGA, C. C., 1994, Contribuição ao estudo da história e geografia do município de São Carlos do Pinhal, Série Documentos. Associação das Escolas Reunidas (Asser), Reeditado (Versão original in Almanach de São Carlos, 1894), 63p. 
BRASIL-EMBRAPA, 1982, Levantamento pedológico semidetalhado do Estado de São Paulo - Quadrícula de Descalvado. Aerofoto Cruzeiro, Secretaria do Abastecimento do Estado de São Paulo, Coordenadoria de Pesquisa Agropecuária, Instituto Agronômico, Divisão de Solos, Seção Pedologia, Rio de Janeiro.

CAMPOS, L. F. G., 1912, Mapa florestal. Sema, São Paulo.

CATHARINO, E. L. M., 1989, Florística de matas ciliares. In: L. M. Barbosa (coord.), Simpósio sobre Mata Ciliar. Anais... Aciesp, pp. 61-67.

CAVASSAN, O., CESAR, O. \& MARTINS, F. R., 1984, Fitossociologia da vegetação arbórea da Reserva Estadual de Baurú, Estado de São Paulo. Revta. Brasil. Bot., 7: 91-106.

COUTINHO, L. M., 1978, O conceito de cerrado. Revta. Brasil. Bot., 1(1): 17-23.

DUARTE, L., 1993, Restos de araucariáceas da formação santana - membro do crato (Aptiano), NE do Brasil. An. Acad. Bras. Ci., 65(4): 357-362.

EMBRAPA-CPPSE, 1999, Microbacia hidrográfica do Ribeirão Canchim: um modelo real de laboratório ambiental. Boletim de Pesquisa, 5. Embrapa Pecuária Sudeste, São Carlos.

EMBRAPA, 2002, Monitoramento por satélite. www.cdbrasil.cnpm. embrapa.br.

FERNANDEZ, A. \& BEZERRA, P., 1990, Estudo fitogeográfico do Brasil. Stylus Comunicações, Fortaleza.

FIBGE, 1993, Mapa de vegetação do Brasil. Fundação do Instituto Brasileiro de Geografia e Estatística, Ministério da Agricultura, Rio de Janeiro.

FUNDAÇÃO SOS MATA ATLÂNTICA, 2001, http://www. sosmataatlantica.com.br.

GIULIETTE, A. M., 1992, Biodiversidade da região Sudeste. Rev. Inst. Flor., 4: 303-305.

HORA, R. C. \& SOARES, J. J., 2002, Estrutura fitossociológica da comunidade de lianas em uma floresta estacional semidecidual na Fazenda Canchim, São Carlos, SP. Revta. Brasil. Bot. (in press).

HUEK, K., 1972, As florestas da América do Sul. Polígono, São Paulo.

IBGE, 1971, Carta do Brasil. Quadrícula de Ibaté, São Carlos e Porto Ferreira.

IVANAUSKAS, N. M., RODRIGUES, R. R. \& NAVE, A. G., 1997, Aspectos ecológicos de um trecho de floresta de brejo em Itatinga, SP: florística, fitossociologia e seletividade de espécies. Revta. Brasil. Bot., 20(2): 139-153.

JARENKOW, J. A. \& BAPTISTA, L. R. M., 1987, Composição florística e estrutura da mata com araucária na Estação Ecológica de Aracuri, Esmeralda, Rio Grande do Sul. Napaea, 3: 9-19.

JOLY, A. B., 1970, Conheça a vegetação brasileira. EduspPolígono, São Paulo, 70p.

LEDRU, M. P., BERTAUX, J., SIFEDDINE, A. \& SUGUIO, K., 1998, Absence of last maximum records in lowland tropical forests. Quartenary Research., 49: 233-237.

LEDRU, M. P., BRAGA, P. I. S., SOUBIÈS, F., FOUNIER, M., MARTIN, L., SUGUIO, K. \& TURCQ, B., 1996, The last 50,000 years in the Neotropics (Southern Brazil): evolution of vegetation and climate. Paleogeography, Paleoclimatology, Paleoecology, 123: 239-257.
LEITÃO FILHO, H. F., 1982, Aspectos taxonômicos das florestas do Estado de São Paulo. In: Cong. Nacional sobre Essências Nativas. Anais... Campos do Jordão, pp. 197-206.

LINDMAN, C. A. M. \& FERRI, M. G., 1974, A vegetação do Rio Grande do Sul. Edusp-Itatiaia, 360p.

MANTOVANI, W., 1989, Conceituação e fatores condicionantes. In: L. M. Barbosa (cood.), Simpósio sobre Mata Ciliar. Anais... Ed. Aciesp, São Paulo, pp. 11-19.

MARTINS, F. R., 1991, Estrutura de uma floresta mesófila. Campinas, Unicamp.

NEVES, A. P. das, 1983, O jardim público de São Carlos do Pinhal. EESC/USP, São Carlos.

PAGANO, S. N. \& LEITÃO FILHO, H. F., 1987, Composição florística do estrato arbóreo de mata mesófila semidecídua no município de Rio Claro (Estado de São Paulo). Rev. Bras. Bot., 10: 37-47.

RODRIGUES, R. R., 1992, Análise da vegetação às margens do Rio Passa Cinco, Ipeúna, SP. Tese de Doutorado, Unicamp.

RODRIGUES, R. R., 2000, Uma discussão nomenclatural das formações ciliares. In: Rodrigues, R. R. \& Leitão Filho, H. F. (ed.), Matas ciliares: conservação e recuperação. EduspFapesp, São Paulo, pp. 91-99.

SAMPAIO, A. J. de, 1938, Phytogeografia do Brasil. Companhia Editora Nacional, Rio de Janeiro, $2^{\underline{a}}$ ed.

SILVA, A. S., 1994, Caracterização de três fisionomias do cerrado na Faz. Canchim, São Carlos, SP. Dissertação de Mestrado, PPGERN, UFSCar.

SILVA, D. W., 1996, Estudo florístico e fitossociológico de um remanescente de cerradão na Faz. Canchim, São CarlosSP. Dissertação de Mestrado, PPGERN, UFSCar,

SILVA, L. A. \& SOARES, J. J., 2000, Fitossociologia de um fragmento de mata mesófila semidecídua, São Carlos, SP. In: V Simpósio de Ecossistemas Brasileiros, Vitória, 3: 291-299.

SIQUEIRA, J. C. de, 1981, Utilização popular das plantas do cerrado. Edições Loyola, São Paulo.

TORRES, R. B., MARTINS, F. R. \& KINOSHITA, L. S., 1997, Climate, soil and tree flora relationships in forests in the state of São Paulo, southeastern Brasil. Revta. Brasil. Bot., 20(1): 41-49.

TROPPMAIR, H., 1974, A cobertura vegetal primitiva do Estado de São Paulo baseada em estudos toponímicos, históricos e ecológicos. Cienc. Cult., 26(3): 240-243.

TROPPMAIR, H. \& MACHADO, M. L. A., 1974, Variação da estrutura da mata galeria na bacia do rio Corumbataí (SP) em relação à água do solo, do tipo de margem e do traçado do rio. Biogeografia, 8: 1-28.

TRUZZI, O., 2000, Café e indústria, São Carlos: 1850-1950. EDUFSCar, São Carlos.

VELOSO, H. P. \& GOES FILHO, L., 1982, Fitogeografia brasileira: classificação fisionômica-ecológica da vegetação neotropical. Bolm. Tec. Radambrasil (Série Vegetação), 1: 1-80. 